\title{
Importance of tree basic density in biomass estimation and associated uncertainties: a case of three mangrove species in Tanzania
}

\author{
Marco Andrew Njana ${ }^{1} \cdot$ Henrik Meilby $^{2} \cdot$ Tron Eid $^{3} \cdot$ Eliakimu Zahabu $^{4} \cdot$ \\ Rogers Ernest Malimbwi ${ }^{4}$
}

Received: 26 February 2016 / Accepted: 8 September 2016 / Published online: 13 October 2016

(C) INRA and Springer-Verlag France 2016

\begin{abstract}
- Key message Aboveground and belowground tree basic densities varied between and within the three mangrove species. If appropriately determined and applied, basic density may be useful in estimation of tree biomass. Predictive accuracy of the common (i.e. multi-species) models including aboveground/belowground basic density was better than for common models developed without either basic density. However, species-specific models developed without basic density performed better than common models including basic density.

- Context Reducing Emissions from Deforestation and forest degradation and the role of sustainable forest management, conservation and enhancement of carbon stocks (REDD+) initiatives offer an opportunity for sustainable management of forests including mangroves. In carbon accounting for REDD+, it is required that carbon estimates prepared for monitoring reporting and verification schemes should ensure that all known sources of
\end{abstract}

\section{Handling Editor: Barry Alan Gardiner}

Electronic supplementary material The online version of this article (doi:10.1007/s13595-016-0583-0) contains supplementary material, which is available to authorized users.

Marco Andrew Njana

marconjana2002@yahoo.com

Henrik Meilby

heme@ifro.ku.dk

Tron Eid

tron.eid@nmbu.no

Eliakimu Zahabu

zahabue@yahoo.com uncertainty are minimised as much as possible. However, uncertainties of applying indirect method of biomass determination are poorly understood.

- Aims This study aimed to assess importance of tree basic density in modelling aboveground and belowground biomass and examine uncertainties in estimation of tree biomass using indirect methods.

- Methods This study focused on three dominant mangrove species (Avicennia marina (Forssk.) Vierh, Sonneratia alba J. Smith and Rhizophora mucronata Lam.) in Tanzania. A total of 120 trees were destructively sampled for aboveground biomass, and 30 among them were sampled for belowground biomass. Tree merchantable volume and both aboveground and belowground basic densities were determined. Biomass models including basic density as a predictor variable were developed using the non-linear mixed-effects modelling approach.
Rogers Ernest Malimbwi remalimbwi@yahoo.com

1 Tanzania Forest Services (TFS) Agency, P.O. Box 40832, Dar es Salaam, Tanzania

2 Faculty of Science, University of Copenhagen, Rolighedsvej 23, 1958 Frederiksberg C, Denmark

3 Department of Ecology and Natural Resources Management, Norwegian University of Life Sciences, P.O Box 1432, Ås, Norway

4 Department of Forest Mensuration and Management, Sokoine University of Agriculture, P.O. Box 3013, Morogoro, Tanzania 
- Results Results showed that both tree aboveground and belowground basic density varied significantly between sites between tree species, among individuals of the same species and between tree components. The use of treeand component-specific aboveground basic density resulted in unbiased tree aboveground biomass estimates; however, uncertainties were high when using aboveground basic density values from the Global Wood Density (GWD) database. Predictive accuracy of the common models including aboveground/belowground basic density was better than for the common models developed previously without basic density. However, the species-specific models developed previously without basic density were superior to the common models including basic density developed in the present study.

- Conclusion Tree aboveground and belowground basic densities were useful in modelling tree aboveground and belowground biomass, respectively. This is demonstrated by improved goodness of fit associated with inclusion of basic density. However, species-specific models developed without basic density performed better than common models including basic density. If appropriately determined and applied, basic density may be useful in estimation of tree biomass and hence contribute to improved accuracy of carbon stock estimates for REDD+ and sustainable management of mangroves in general.

Keywords Tree aboveground and belowground biomass . Inter- and intra-tree basic density variation - Biomass models . Indirect tree biomass estimation $\cdot$ Mixed-effects models

\section{Introduction}

Mangroves represent about $0.39 \%$ of global forest cover (FAO 2010) and comprise up to 70 tree species, out of which 14 are growing naturally along the Eastern Coast of Africa (Saenger et al. 1983; Tomlinson, 1986; Aksornkoae et al. 1992). In Tanzania, mangrove forests cover about 158,100 ha (MNRT 2015) and include ten different species, namely Avicenia marina (Forssk.) Vierh., Bruguiera gymnorrhiza (L.) Lamk., Ceriops tagal (Perr.) C. B. Rob., Heritiera littoralis Dryand., Lumnitzera racemosa Willd., Pemphis acidula J.R. \& G. Forst., Rhizophora mucronata Lam., Sonneratia alba J. Smith, Xylocarpus granatum Koen. and Xylocarpus moluccensis (Lamk.) Roem. These species also appear in Kenya and Mozambique (Tamooh et al. 2008; Fatoyinbo et al. 2008). A. marina, S. alba and R. mucronata are the most abundant species in Tanzania (Luoga et al. 2004; Nshare et al. 2007).

Mangroves are important for biological, ecological, economic and protection reasons (Kristensen et al. 2008; Spalding et al. 2010; Nagelkerken et al. 2008; Zhang et al. 2012a). Although mangroves cover relatively small areas, they hold large quantities of carbon per unit area stored in aboveground and belowground biomass (Donato et al. 2011; Duncan et al. 2016). Despite their importance, mangroves are threatened by deforestation and forest degradation, which led to a loss of $35 \%$ of the world's mangrove cover between 1980 and 2000 (Valiela et al. 2001; Langner et al. 2007).

Given the valuable services offered by mangrove ecosystems, their sustainable management is imperative. Unfortunately, most of the services offered by mangroves are non-market services; which may lead to low motivation for effective management of mangroves. However, Reducing Emissions from Deforestation and forest degradation and the role of sustainable forest management, conservation and enhancement of carbon stocks (REDD+) is a potential opportunity with an orientation of supporting conservation and sustainable management of forests such as mangroves (Alongi 2011; Locatelli et al. 2014; Wylie et al. 2016). REDD+ is a system of financing mechanisms and incentives aimed at mitigating climate change by reducing deforestation and forest degradation but also through sustainable management of forests and conservation and enhancement of carbon stocks (Angelsen and Hofstad 2008; UNFCCC 2011). Countries participating in REDD+ projects are required to produce accurate estimates for their forest carbon stocks and changes through robust measurement, reporting and verification (MRV) schemes.

The Intergovernmental Panel on Climate Change (IPCC) emphasises that carbon estimates prepared for MRV schemes should be accompanied by an appropriate measure of uncertainty, while at the same time minimising all known sources of uncertainty (IPCC 2006). Based on previous studies, uncertainties are likely to occur at each of the following stages in biomass quantification: (i) sampling design, (ii) field measurements, (iii) selection of biomass model and (iv) selection of basic density values when used as a biomass predictor variable (Ketterings et al. 2001; Chave et al. 2004; Henry et al. 2010; Clark and Kellner 2012).

Biomass can be quantified in different ways, but most commonly by applying a biomass model to forest inventory data, leading to single tree or stand and landscape level estimates. Development of biomass models requires destructive sampling of trees. Selected sample trees are felled and partitioned into tree components such as stems, branches, and twigs and leaves. The merchantable part of the tree, i.e. stem and branches defined by a minimum top diameter (IPCC 2006), is then crosscut into billets, which can be measured for fresh weight and/or fresh volume over bark. Thus, tree aboveground biomass estimates from which carbon stock is derived may be determined using either (1) direct tree aboveground biomass determination method which involves determining fresh weight which is converted to dry weight using a dry to fresh weight ratio or (2) indirect tree aboveground biomass determination method which involves determining fresh volume which is converted to dry weight using aboveground 
basic density. The indirect method is often suggested for sampling large trees because the direct method is labour intensive and costly (Brown 1997; Picard et al. 2012).

For both direct and indirect methods however, the nonmerchantable part of the tree has to be determined for fresh weight, which is converted to dry weight using a dry to fresh weight ratio estimate. Merchantable and non-merchantable dry weights are then summed to get the total tree dry weight. The total tree dry weight obtained through either of the two methods of biomass estimation may be used to develop biomass models.

For the indirect aboveground biomass determination method, however, the accuracy of determining aboveground biomass based on the volume of part of a tree (merchantable part) is unknown. Extraction of sub-samples from sample trees for determination of both aboveground and belowground basic density without knowledge on how it varies between species, within trees, among individuals of the same species and between sites may introduce uncertainties when such values are applied as volume to biomass conversion factors or predictor variables.

Most biomass models for mangroves include tree diameter at breast height $(d b h)$ as the only predictor variable (e.g. Komiyama et al. 2005), but some models also include total tree height $(h t)$ as a second predictor variable (e.g. Komiyama et al. 2008). Yet, other authors take into account that for some tree species, basic density varies between sites and therefore include this variable as a second or third predictor variable in developing models that are valid across sites and species (multi-species models) (e.g. Chave et al. 2005; Komiyama et al. 2005).

According to Chave et al. (2005), in decreasing order of importance, $d b h$, aboveground basic density and $h t$ are the most important predictor variables of tree aboveground biomass. Recently, Njana et al. (2016) reported aboveground and belowground biomass models for A. marina, S. alba and $R$. mucronata in Tanzania with $d b h$ only and both $d b h$ and $h t$ as predictor variables. The main argument for not including basic density as predictor variable in the models for the purpose of improving their predictive accuracy was that the nonlinear mixed-effects modelling approach was regarded as sufficiently robust in distinguishing species when using species as a random-effects variable. Conversely, assuming that basic density varies between trees and sites, its inclusion may potentially make the models more accurate when applied at a mangrove site outside the sampling frame.

To minimise propagation of uncertainties in subsequent stages of biomass estimation at stand or landscape levels, it is important that uncertainties in tree or sub-tree biomass estimates are identified, quantified and minimised. Focusing on the three dominant mangrove species in Tanzania, A. marina, $S$. alba and R. mucronata, our study therefore aimed (i) to determine and assess variations of tree aboveground and belowground basic density between and within species; (ii) to test the hypothesis that during destructive sampling, the indirect method of determining tree aboveground biomass (from volume using aboveground basic density as a conversion factor) yields as accurate estimates as does the direct method (actual weighing) and (iii) to investigate the importance of including aboveground and belowground basic density as a predictor variable of tree aboveground and belowground biomass, respectively.

\section{Methods}

\subsection{Study area}

The present study was carried out at four sites along the coastline of Tanzania. The sites included Pangani $\left(5^{\circ} 38^{\prime} \mathrm{S}, 38^{\circ} 54^{\prime}\right.$ $\mathrm{E}$ to $\left.5^{\circ} 40^{\prime} \mathrm{S}, 38^{\circ} 53^{\prime} \mathrm{E}\right)$, Bagamoyo $\left(6^{\circ} 20^{\prime} \mathrm{S}, 38^{\circ} 50^{\prime} \mathrm{E}\right.$ to $6^{\circ}$ $33^{\prime} \mathrm{S}, 39^{\circ} 06^{\prime} \mathrm{E}$ ), Rufiji ( $7^{\circ} 38^{\prime} \mathrm{S}, 39^{\circ} 16^{\prime} \mathrm{E}$ to $7^{\circ} 55^{\prime} \mathrm{S}, 39^{\circ} 24^{\prime}$ E) and Lindi $\left(10^{\circ} 02^{\prime} \mathrm{S}, 39^{\circ} 39^{\prime} \mathrm{E}\right)$-Mtwara $\left(10^{\circ} 23^{\prime} \mathrm{S}, 40^{\circ} 23^{\prime}\right.$ E). The climate in the study area is influenced by north-east monsoon winds from October to March and south-east monsoon winds from April to October. Average annual rainfall varies from $879 \mathrm{~mm}$ (Rufiji) to $1240 \mathrm{~mm}$ (Pangani) while average annual temperatures range from $25.7^{\circ} \mathrm{C}$ (Lindi) to $27.0^{\circ} \mathrm{C}$ (Rufiji).

\subsection{Plot sampling, measurements of standing trees and tree selection}

Generally, site conditions in mangrove forests vary across and not along the sea or river shores. To cover as much variation as possible, we established 37 transects running from the edge of the sea or river across the entire expanse of the mangrove vegetation. Within each transect, one to four circular plots were established, the first plot being located close to the edge of the sea/river (for details, see Njana et al. 2015). The remaining plots were distributed along the transect lines with intervals ranging from 150 to $250 \mathrm{~m}$. A total of 120 plots were established using a nested plot design.

Within each plot, one tree was selected for destructive sampling, thus making up a total of 120 trees ( 40 for each of the three species, A. marina, S. alba and R. mucronata). Among the 120 trees (sampled for aboveground basic density, aboveground biomass and aboveground merchantable fresh volume), roots of 30 trees (10 for each of the three species) were excavated for determination of tree belowground basic density and belowground biomass. Fifteen trees ( 5 for each species) were sampled at each of the sites in Pangani and LindiMtwara, and 45 trees (15 for each species) were sampled at each of the sites in Bagamoyo and Rufiji.

The sample trees were selected purposively to ensure adequate representation of each of the three species across sites and $d b h$ ranges. In the selection of trees for root excavation 
( $n=30$ ), the feasibility of belowground sampling was also considered to make excavation less destructive. The sampling procedures are detailed by Njana et al. (2015).

For all sample trees of $A$. marina and $S$. alba, we measured $d b h$ and $h t$. For $R$. mucronata, we measured the same parameters, but $h t$ was measured from the highest stilt root to the highest living part of a tree. Three $R$. mucronata sample trees were multi-stemmed. For these trees, diameters of individual stems $\left(d b h_{i}\right)$ were combined and a surrogate for $d b h$ was determined as $d b h=\sqrt{\sum\left(d b h_{i}\right)^{2}}$ (e.g. Zhou et al. 2007). Diameters of trees harvested for aboveground biomass estimation ranged from 1.1 to $70.5,1.1$ to 63.6 and 1.4 to $41.5 \mathrm{~cm}$ for A. marina, S. alba and $R$. mucronata respectively. Similarly, for excavated trees, diameter varied from 3.0 to $38.6 \mathrm{~cm}$ for A. marina, 6.5 to $33.8 \mathrm{~cm}$ for $S$. alba and 1.4 to $32.6 \mathrm{~cm}$ for $R$. mucronata. Details are provided by Njana et al. (2015) and Njana et al. (2016).

\subsection{Destructive sampling}

The sampling aimed at generating data for determination of tree aboveground basic density, aboveground biomass, aboveground fresh volume, belowground basic density and belowground biomass. Basic density is defined as oven-dry mass divided by fresh volume expressed in tons per cubic metre, kilograms per cubic metre or grams per cubic centimetre (Williamson and Wiemann 2010; Wiemann and Williamson 2012). Aboveground tree components included stem, branch and twig and leaf, while belowground tree components included root crown and root (see Njana et al. 2016).

Using a chainsaw, sample trees were cut $15 \mathrm{~cm}$ above the soil surface (A. marina and $S$. alba) or immediately above the highest stilt root ( $R$. mucronata). After felling a tree, the aboveground part was divided into three components, (i) stems, (ii) branches $(\geq 5 \mathrm{~cm}$ diameter) and (iii) twigs ( $<5 \mathrm{~cm}$ diameter), and leaves for trees with $d b h \geq 15 \mathrm{~cm}$. Stems and branches were cross-cut into billets. Fresh weights of large billets (diameter $\geq 5 \mathrm{~cm}$ ) were determined using a spring balance (to the nearest $0.1 \mathrm{~kg}$ ).

Furthermore, for each sample tree with $d b h \geq 15 \mathrm{~cm}$, the cross-cut stem and branch billets (diameter $\geq 5 \mathrm{~cm}$ ) were recorded for mid-diameter $(\mathrm{cm})$ and length $(\mathrm{m})$ in order to determine merchantable volume. By merchantable volume, we mean the volume of the tree including stem and branches to a fixed top diameter of $5 \mathrm{~cm}$. The number of trees with $d b h$ $\geq 15 \mathrm{~cm}$ were 22 (A. marina), 12 (S. alba) and 21 (R. mucronata).

From each sample tree, we extracted three sub-samples from stems, two from branches and two from twigs for determination of aboveground basic density and dry to fresh weight ratio. All sub-samples included bark (Fearnside 1997; Somogyi et al. 2007). Sub-samples from all aboveground tree components except for stems were extracted at random. For stems, sub-samples were extracted at 0,40 and $70 \%$ of total tree height (e.g. Githiomi and Kariuki 2010).

To determine belowground basic density and belowground biomass, root crown and roots were excavated. For A. marina and $S$. alba, the belowground part consisted of root crown and roots (see Fig. 1); for R. mucronata, it consisted of root crown, aboveground stilt roots and belowground stilt roots (see Fig. 2). For A. marina and S. alba, belowground biomass was quantified using a root sampling approach (not all roots were excavated). Root crown and selected roots were fully excavated and their dry weights recorded. Basal diameter for both excavated and unexcavated roots were recorded. For $R$. mucronata, roots were excavated entirely and root crown and all aboveground stilt roots were harvested. All belowground stilt roots were also fully excavated (see Njana et al. 2015). For all the three species, sub-samples from the root crown were collected by slicing the root crown from the top and downwards so as to secure an appropriate vertical representation. In addition, sub-samples were extracted from randomly selected locations along the length of main and side cable roots (A. marina and $S$. alba). For R. mucronata, in addition to sub-samples from the root crown, sub-samples were also collected from randomly selected locations on aboveground and belowground stilt roots.

After extraction of sub-samples, their fresh weight was immediately determined using a digital balance (to the nearest $0.01 \mathrm{~g}$ ). This was followed by labelling and packing for further measurements in the laboratory.

\subsection{Laboratory procedures}

In the laboratory, sub-samples were soaked in distilled water and fresh volume determined by water displacement (Brown 1997). Subsequently, sub-samples were oven-dried to constant weight at $105^{\circ} \mathrm{C}$ and their dry weight determined using a digital balance (Picard et al. 2012).

\subsection{Determination of basic density, dry to fresh weight ratio, tree biomass and volume}

For each tree component sub-sample, basic density was determined as oven-dry weight (g) per fresh volume $\left(\mathrm{cm}^{3}\right)$. Dry to fresh weight ratio was determined as the ratio of sub-sample dry to fresh weight. Exploratory analysis of covariance (ANCOVA) for dry to fresh weight ratios, where $d b h$ served as a covariate, revealed that they varied significantly between aboveground tree components and with tree size $(p<0.05)$.

Total observed fresh weight of each aboveground component was obtained by summation. Total observed tree 
Fig. 1 A. marina and S. alba tree root system (modified from Purnobasuki 2013); the dashed lines indicate cut-off points between root crown and main cable roots and between main cable roots and side cable roots

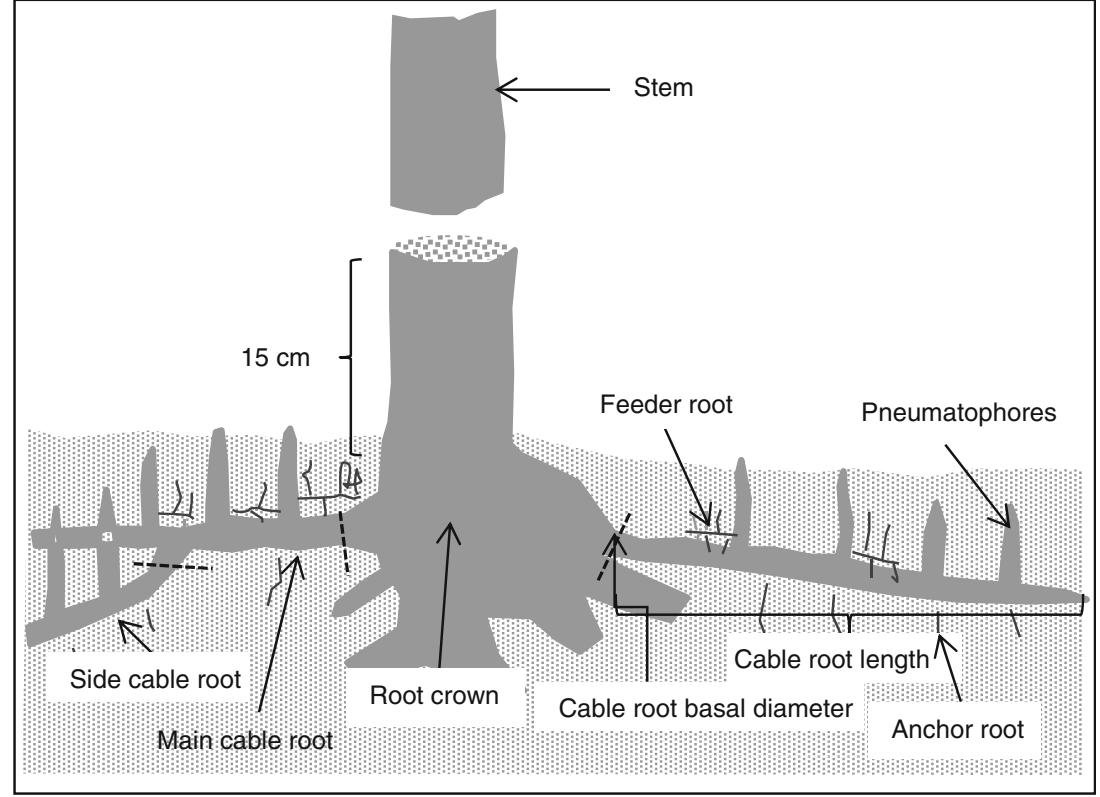

aboveground biomass was calculated as the sum of the products of tree- and component-specific fresh weights and dry to fresh weight ratios (Eq. 1).

$$
\begin{aligned}
\mathrm{AGB}_{i_{o b s}} & =\left(\sum_{j_{s}=1}^{n_{s}}\left(\mathrm{FW}_{i j_{s}}\right) * \mathrm{DF}_{i j_{s}}\right)+\left(\sum_{j_{b}=1}^{n_{b}}\left(\mathrm{FW}_{i j_{b}}\right) * \mathrm{DF}_{i j_{b}}\right) \\
& +\left(\sum_{j_{t}=1}^{n_{t}}\left(\mathrm{FW}_{i j_{t}}\right) * \mathrm{DF}_{i j_{t}}\right)+\left(\sum_{j_{l}=1}^{n_{l}}\left(\mathrm{FW}_{i j_{l}}\right) * \mathrm{DF}_{i j_{l}}\right)
\end{aligned}
$$

where $n=$ total number of billets/twig bundles/leaf weights for a given aboveground tree component, $s=$ stem, $b=$ branch, $t=$ twig, $l=$ leaf, $i=i$ th tree, $j=j$ th sub-section/bundle of twigs or leaves, $\mathrm{AGB}_{i_{\text {obs }}}=$ observed total tree aboveground dry weight (kg), $\mathrm{FW}_{i j_{s}}, \mathrm{FW}_{i j_{b}}, \mathrm{FW}_{i j_{l}}$ and $\mathrm{FW}_{i j_{l}}$ are stem, branch, twig and leaf fresh weights $(\mathrm{kg})$ respectively and $\mathrm{DF}_{i j_{s}}, \mathrm{DF}_{i j_{b}}$, $\mathrm{DF}_{i j_{t}}$ and $\mathrm{DF}_{i j_{l}}$ are stem, branch, twig and leaf dry to fresh weight ratios, respectively.

The volume of individual billets was computed using Huber's formula (e.g. West 2009). Merchantable volume was calculated as the sum of the volumes of all billets for each tree component (stem, branches). We applied tree- and component-specific aboveground basic density values to convert merchantable volume to biomass. Tree-specific and species-specific mean aboveground basic density values from this study were also tested. In addition, we applied species-
Fig. 2 R. mucronata tree root system; the dashed lines indicate cut-off points between root crown and stilt roots

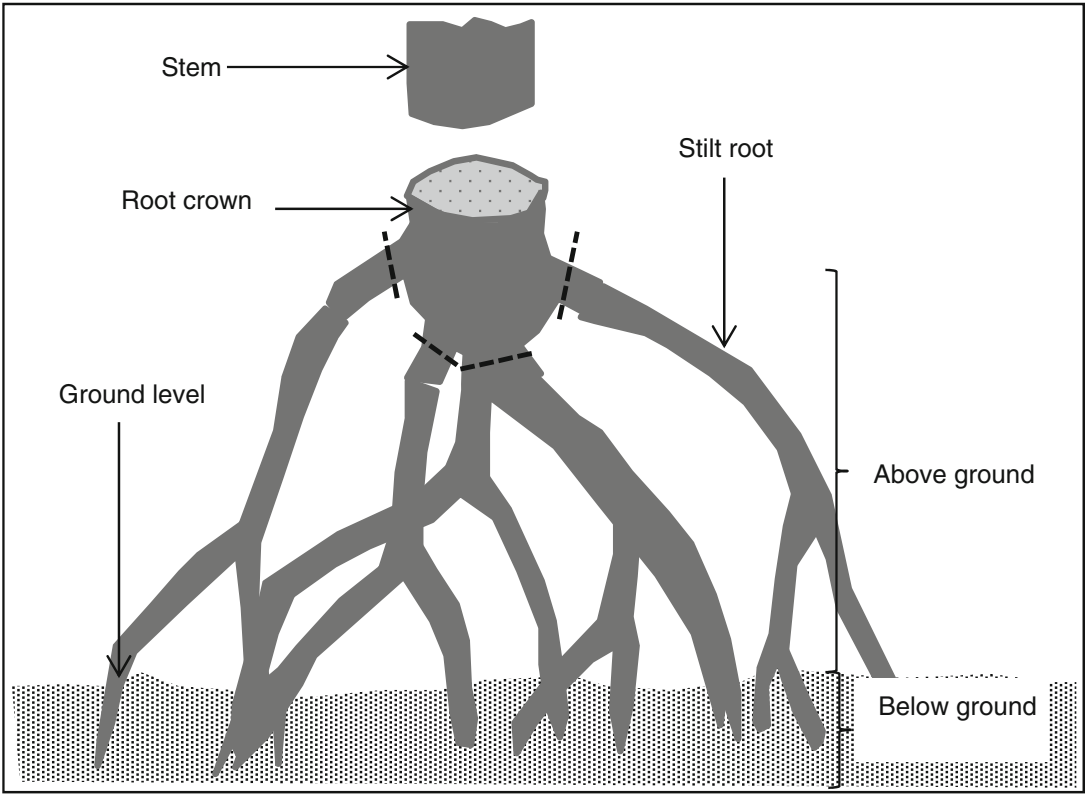


specific aboveground basic density values from the Global Wood Density (GWD) database (Chave et al. 2009; Zanne et al. 2009). The estimated tree aboveground biomass was calculated using Eq. 2.

$$
\begin{aligned}
\mathrm{AGB}_{i_{e s t}} & =\left(\sum_{j_{s}=1}^{n_{s}}\left(\mathrm{FV}_{i j_{s}}\right) * \mathrm{BD}_{i j_{s}}\right)+\left(\sum_{j_{b}=1}^{n_{b}}\left(\mathrm{FV}_{i j_{b}}\right) * \mathrm{BD}_{i j_{b}}\right) \\
& +\left(\sum_{j_{t}=1}^{n_{t}}\left(\mathrm{FW}_{i j_{t}}\right) * \mathrm{DF}_{i j_{t}}\right)+\left(\sum_{j_{l}=1}^{n_{l}}\left(\mathrm{FW}_{i j_{l}}\right) * \mathrm{DF}_{i j_{l}}\right)
\end{aligned}
$$

where $n=$ total number of billets/twig bundles/leaf weights for a given aboveground tree component, $s=$ stem, $b=$ branch, $t=$ twig, $l=$ leaf,$i=i$ th tree, $j=j$ th sub-section/bundle of twigs or leaves, $\mathrm{AGB}_{h_{\text {est }}}=$ estimated total tree aboveground dry weight $(\mathrm{kg}), \mathrm{FV}_{i j_{s}}$ and $\mathrm{FV}_{i j_{b}}$ are stem and branch fresh volume $\left(\mathrm{m}^{3}\right)$, respectively and $\mathrm{BD}_{i j_{s}}$ and $\mathrm{BD}_{i j_{b}}$ are stem and branch basic density values, respectively. Other abbreviations are as defined previously.

Using excavated cable root data (A. marina and S. alba), regression models were developed with root dry weight as a response variable and basal root diameter as a predictor variable (see Njana et al. 2015). The dry weight models were then applied to predict dry weights of unexcavated roots. Total belowground biomass was derived as the sum of the dry weights of root crown and roots (excavated and unexcavated). For $R$. mucronata, belowground biomass included root crown and aboveground and belowground stilt roots as defined by Komiyama et al. (2005), Ong et al. (2004) and Comley and McGuinness (2005).

\subsection{Statistical data analysis}

Data was analysed using R software (R Core Team 2013). We initially analysed variation of aboveground and belowground basic density between species followed by determination of inter- and intra-tree basic density variation. To prepare a basis for analysing inter-tree basic density variation, mean aboveground and belowground basic densities were calculated for each tree. The potential determinants of inter-tree basic density variation were selected based on previous studies (e.g. Zhang et al. 2012b; Auty et al. 2014) which included number of trees per hectare $(N)$ (no. of trees $\mathrm{ha}^{-1}$ ), basal area per hectare $(G)\left(\mathrm{m}^{2} \mathrm{ha}^{-1}\right), d b h$ class $(10 \mathrm{~cm}$ classes $)$ and study site.

Variation of aboveground and belowground basic density between tree species was determined using linear mixedeffects model (LMM) procedures (Gałecki and Burzykowski 2013), where species served as a fixed-effects variable. The use of LMM was motivated by the hierarchical structure of the data used in this study since tree basic density observations were nested within site; site was considered as a randomeffects variable. Model fitting was done using the lme function in the nlme package. The significance of species differences in explaining the variation of basic density was determined by $F$ tests. Post hoc tests were carried out using the glht function in multcomp package (Bretz et al. 2011).

Preliminary analysis indicated that $N, G$ and $d b h$ class were either uncorrelated or approximately linearly related with tree basic density. Therefore, for each of the three species, the influence of these variables on aboveground and belowground basic density, together with study site, was determined using LMM. In this case $N, G, d b h$ class and site served as fixedeffects variables. Models were fitted as described earlier.

We also determined variation in aboveground and belowground basic density between tree components (intra-tree variation) using LMMs. In this case, tree component was treated as a fixed-effects variable. Subsequently, variation of aboveground and belowground basic density within tree component was examined. For stems, the analysis considered variation along stem (i.e. intra-tree variation) using data from the three different sampling heights, i.e. 0,40 , and $70 \%$ of total tree height. Since basic density data were nested, they were analysed using LMM where stem absolute sampling height was treated as a fixed-effects variable (stem) and site and tree as random-effects variables (all components). Model fitting and post hoc tests followed procedures described previously.

Ninety-five percent confidence intervals for both observed tree aboveground biomass (i.e. obtained using the direct method involving actual weighing and derived using Eq. 1) and estimated tree aboveground biomass (i.e. obtained indirectly using products of volume and aboveground basic density and derived using Eq. 2) were determined. Subsequently, accuracy of the indirect method of aboveground biomass determination was assessed using percentage mean prediction error (MPE (\%)) calculated as average of estimated aboveground biomass minus observed aboveground biomass relative to observed aboveground biomass. Positive MPE (\%) values and significantly different from zero signified over-estimation of tree aboveground biomass (i.e. positive bias). Similarly, negative MPE (\%) values and significantly different from zero signified under-estimation of tree aboveground biomass (i.e. negative bias). Conversely, tree aboveground biomass estimates with non-significant MPE (\%) values were considered unbiased (Walther and Moore 2005; IPCC 2003).

Explorative analysis revealed that the relationships between aboveground and belowground biomass and $d b h$ were non-linear (Njana et al. 2016). We therefore initially tested several options to describe the non-linear relationships (e.g. second-order polynomial function, exponential function) where the power function was the best. The power function has also been widely used to describe similar relationships (e.g. Komiyama et al. 2008). Therefore, using Eqs. 3 and 4, aboveground biomass and belowground biomass models were developed using the non-linear mixed-effects modelling (NLME) approach (Pinheiro and Bates 2000): 
$B_{i k m}=\beta_{0} * \mathrm{dbh}_{i k m}\left(\beta_{1}+\alpha_{k m}\right) * \mathrm{BD}_{i k m}{ }^{\beta_{2}}+\varepsilon_{i k m}$

$B_{i k m}=\beta_{0} * \mathrm{dbh}_{i k m}\left(\beta_{1}+\alpha_{k m}\right) * \mathrm{ht}_{i k m}{ }^{\beta_{2}} * \mathrm{BD}_{i k m}{ }^{\beta_{3}}+\varepsilon_{i k m}$

where $B_{i k m}$ is either aboveground biomass or belowground biomass $\left(\mathrm{kg}\right.$ tree $\left.{ }^{-1}\right)$ of tree $i$ for species $k$ in site $m ; B D_{i k m}$ is either aboveground or belowground basic density of tree $i$ for species $k$ in site $m ; \beta_{0}, \beta_{1}$ and $\beta_{2}$ are fixed-effects parameters; $\alpha_{k m}$ is a random-effects parameter for species $k$ in site $m$ (associated with $\left.\beta_{1}\right) ; \mathrm{dbh}_{i k m}$ and $\mathrm{ht}_{i k m}$ are the $d b h$ and $h t$ of tree $i$, respectively, and $\varepsilon_{i k m}$ is the error term for tree $i$, species $k$ at site $m$, which is assumed to be normally distributed with mean 0 and variance $\sigma^{2}$. Model fitting was done using the nlme function in the nlme package.

To assess the importance of basic density in modelling tree aboveground and belowground biomass, models based on Eqs. 3 and 4 above were compared with common models (CMs)/fixed-effects (FE) models (FE1, FE2 and FE3) and their corresponding species-specific models/random-effects (RE) models (RE1, RE2, RE3, RE4, RE5, RE6, RE7, RE8 and RE9) reported recently by Njana et al. (2016) (see Table A1; Online Appendix).

Models based on Eq. 3 were compared with models FE1 and FE3, while models based on Eq. 4 were compared with model FE2. Common models including basic density were also compared with species-specific models developed previously without basic density (Njana et al. 2016). Model comparison for the purpose of determining the importance of aboveground and belowground basic density in modelling tree biomass was possible because Eq. 3 is a reduced version of Eq. 4 and because the models are based on the same data and modelling approach. If inclusion of aboveground or belowground basic density in a model resulted in lower percentage MPE (\%) and Akaike information criteria (AIC), the models were considered as improved, thus implying that aboveground and belowground basic density was useful in modelling tree aboveground and belowground biomass, respectively.

\section{Results}

\subsection{Basic density values and variations}

Basic density values for aboveground and belowground tree components as well as whole trees (overall) are summarised in Table 1. Results based on LMM revealed a significant variation of tree aboveground basic density $\left(F_{(2,112)}=195.41, p<0.001\right)$ and belowground basic density $\left(F_{(2,23)}=29.34, p<0.001\right)$ between species. Post hoc tests for multiple comparisons indicated that all pairwise comparisons were significant at the $0.1 \%$ level, except for the belowground basic densities of $A$. marina and $R$. mucronata, which were not significantly different $(p>0.05)$.

Mixed results were observed for factors considered as determinants for variation in basic density (Table 2). In most cases, the relationships based on Spearman correlation were weak and statistically insignificant ( $p \geq 0.05)$, especially for belowground basic density for all the three species. Strong relationships were observed between aboveground basic density and $N$ (A. marina), aboveground basic density and $G$ (S. alba) and aboveground basic density and $d b h$ ( $S$. alba and $R$. mucronata). Similarly, site was a significant source of variation for aboveground basic density ( $S$. alba and R. mucronata). The relationship between aboveground basic density and $d b h$ was generally positive and non-linear while the relationship between belowground basic density and $d b h$ was positive and linear for all the three species (Table 2).

For aboveground basic density, the intra-tree variation was significant for R. mucronata and S. alba while for belowground basic density, it was significant for A. marina and R. mucronata (Table 3). The results also showed that within the stem component, basic density varied with sampling height. The variation was significant for $S$. alba $\left(F_{(1,}\right.$ 114) $=7.80, p<0.001)$ but not for the other two species. For other tree components, basic density varied significantly among twigs $(p<0.05)$ and branches $(p<0.01)$ for A. marina, among roots $(p<0.01)$ for $S$. alba and among belowground stilt roots $(p<0.01)$ for $R$. mucronata. In all other cases, the variations within tree components were statistically insignificant $(p \geq 0.05)$.

\subsection{Accuracy and precision of tree aboveground biomass estimation using aboveground basic density as a conversion factor}

The use of tree- and component-specific basic density in estimation of tree aboveground biomass (using Eq. 2) resulted in unbiased tree aboveground biomass estimates $(p>0.05)$ for all three species (Table 4). On the other hand, the use of species-specific mean (overall) from this study (Table 4) or from the GWD database resulted in biased tree aboveground biomass estimates $(p<0.05)$ for $S$. alba and $R$. mucronata.

\subsection{Importance of basic density in modelling tree aboveground and belowground basic density}

The importance of using aboveground and belowground basic density in modelling tree aboveground and belowground biomass, respectively was examined through development of aboveground or belowground biomass models including aboveground and belowground basic density as a predictor variable and comparing these models with models including $d b h$ only and $d b h$ and $h t$ reported previously by Njana et al. (2016) (Table 5). The use of site and species as random-effects 
Table 1 Descriptive statistics on distribution of tree aboveground and belowground basic density $\left(\mathrm{g} \mathrm{cm}^{-3}\right)$ for the three mangrove species

\begin{tabular}{|c|c|c|c|c|c|c|c|c|c|c|c|c|c|c|c|}
\hline \multirow{2}{*}{$\begin{array}{l}\text { Basic density/ } \\
\text { component }\end{array}$} & \multicolumn{5}{|c|}{ A. marina } & \multicolumn{5}{|l|}{ S. alba } & \multicolumn{5}{|c|}{ R. mucronata } \\
\hline & $n$ & Mean \pm SE & STD & Min. & Max. & $n$ & Mean $\pm \mathrm{SE}$ & STD & Min. & Max. & $n$ & Mean $\pm \mathrm{SE}$ & STD & Min. & Max \\
\hline \multicolumn{16}{|l|}{$\begin{array}{l}\text { Aboveground basic } \\
\text { density }\end{array}$} \\
\hline Twig & $38(72)$ & $0.59 \pm 0.01$ & 0.05 & 0.43 & 0.69 & $35(68)$ & $0.51 \pm 0.01$ & 0.06 & 0.35 & 0.73 & 37 (72) & $0.61 \pm 0.01$ & 0.04 & 0.53 & 0.70 \\
\hline Branch & $27(50)$ & $0.59 \pm 0.01$ & 0.03 & 0.48 & 0.67 & $20(39)$ & $0.52 \pm 0.01$ & 0.03 & 0.45 & 0.59 & $24(46)$ & $0.70 \pm 0.01$ & 0.06 & 0.44 & 0.83 \\
\hline Stem & 40 (119) & $0.60 \pm 0.00$ & 0.05 & 0.50 & 0.74 & $40(118)$ & $0.56 \pm 0.01$ & 0.09 & 0.32 & 0.65 & $39(117)$ & $0.71 \pm 0.01$ & 0.07 & 0.56 & 0.84 \\
\hline $\begin{array}{l}\text { Overall (species- } \\
\text { specific mean) }\end{array}$ & $40(241)$ & $0.60 \pm 0.00$ & 0.03 & 0.54 & 0.67 & $40(225)$ & $0.54 \pm 0.01$ & 0.04 & 0.43 & 0.59 & $40(235)$ & $0.69 \pm 0.01$ & 0.04 & 0.58 & 0.73 \\
\hline \multicolumn{16}{|l|}{$\begin{array}{l}\text { Belowground basic } \\
\text { density }\end{array}$} \\
\hline Root crown & $10(10)$ & $0.61 \pm 0.02$ & 0.07 & 0.46 & 0.72 & $10(10)$ & $0.34 \pm 0.02$ & 0.09 & 0.24 & 0.53 & $7(7)$ & $0.73 \pm 0.02$ & 0.05 & 0.66 & 0.84 \\
\hline Root & $10(19)$ & $0.45 \pm 0.02$ & 0.08 & 0.32 & 0.53 & $10(19)$ & $0.29 \pm 0.02$ & 0.05 & 0.23 & 0.42 & - & - & & & \\
\hline $\begin{array}{l}\text { Aboveground } \\
\text { stilt root }\end{array}$ & - & - & - & - & - & - & - & - & - & - & $9(17)$ & $0.59 \pm 0.01$ & 0.04 & 0.49 & 0.65 \\
\hline $\begin{array}{l}\text { Belowground } \\
\text { stilt root }\end{array}$ & - & - & - & - & - & - & - & - & - & - & $10(19)$ & $0.27 \pm 0.05$ & 0.16 & 0.12 & 0.63 \\
\hline $\begin{array}{l}\text { Overall (species- } \\
\text { specific mean) }\end{array}$ & $30(29)$ & $0.57 \pm 0.02$ & 0.07 & 0.39 & 0.61 & $10(29)$ & $0.32 \pm 0.01$ & 0.04 & 0.24 & 0.38 & $10(43)$ & $0.53 \pm 0.02$ & 0.05 & 0.56 & 0.61 \\
\hline
\end{tabular}

Note: Since basic density varies between trees, the basic density average values represent weighted mean using tree aboveground biomass for aboveground basic density and tree belowground biomass for belowground basic density as weights.

$S E$ standard error of a mean, $n$ number outside brackets represents of sample trees while those in brackets represent sub-samples extracted from sample trees

variables seemingly improved the goodness of fit, but the parameter estimates were not significant and the models were therefore not reported.

Inclusion of tree-specific mean aboveground basic density and species-specific mean aboveground basic density in the tree aboveground biomass models resulted in a decline of AIC when our common models (CM1, CM2, CM3 and CM4, Table 5) were compared with those reported by Njana et al. (2016) (FE1 and FE2, Table A1, Online Appendix). Among the tree aboveground biomass models developed in this study, the common models based on species-specific mean aboveground basic density (CM2, CM4) gave the best result as indicated by the lowest AIC. Notwithstanding the fact that the significance of the parameters used in these models is very different from the calculations of tree aboveground biomass (Table 4), it is interesting that the use of species-specific mean aboveground basic density in modelling tree aboveground biomass resulted in lower AIC (Table 5).

With reference to the model reported by Njana et al. (2016) for tree belowground biomass (FE3), neither tree-specific nor species-specific mean aboveground basic density was useful in modelling tree belowground biomass since their inclusion in the

Table 2 Inter-tree aboveground and belowground basic density variation for three mangrove species

\begin{tabular}{|c|c|c|c|c|c|c|c|c|c|c|}
\hline \multirow[t]{2}{*}{ Sources of variation } & \multirow[t]{2}{*}{ Category } & \multicolumn{3}{|c|}{ A. marina } & \multicolumn{3}{|c|}{ S. alba } & \multicolumn{3}{|c|}{ R. mucronata } \\
\hline & & $d f$ & $F$ & $r$ & $d f$ & $F$ & $r$ & $d f$ & $F$ & $r$ \\
\hline \multirow[t]{2}{*}{$N\left(\mathrm{ha}^{-1}\right)$} & $A G B D$ & 1,33 & $6.85^{* * *}$ & $-0.40^{* *}$ & 1,33 & $0.79 \mathrm{NS}$ & $0.10 \mathrm{NS}$ & 1,33 & $1.91 \mathrm{NS}$ & $-0.15 \mathrm{NS}$ \\
\hline & $B G B D$ & 1,3 & $1.50 \mathrm{NS}$ & $0.32 \mathrm{NS}$ & 1,3 & $12.41 \mathrm{NS}$ & $-0.32 \mathrm{NS}$ & 1,3 & $2.11 \mathrm{NS}$ & $0.53 \mathrm{NS}$ \\
\hline \multirow[t]{2}{*}{$G\left(\mathrm{~m}^{2} \mathrm{ha}^{-1}\right)$} & $A G B D$ & 1,33 & $0.25 \mathrm{NS}$ & $-0.10 \mathrm{NS}$ & 1,33 & $19.66 * * *$ & $0.44 * *$ & 1,33 & $6.04 *$ & $0.22 \mathrm{NS}$ \\
\hline & $B G B D$ & 1,3 & $0.21 \mathrm{NS}$ & $0.43 \mathrm{NS}$ & 1,3 & $1.40 \mathrm{NS}$ & $-0.37 \mathrm{NS}$ & 1,3 & $0.32 \mathrm{NS}$ & $0.27 \mathrm{NS}$ \\
\hline \multirow[t]{2}{*}{$d b h(\mathrm{~cm})$} & $A G B D$ & 1,33 & $0.61 \mathrm{NS}$ & $0.27 \mathrm{NS}$ & 1,33 & $13.69 * * *$ & $0.69 * * *$ & 1,33 & $7.51 * * *$ & $0.62 * * *$ \\
\hline & $B G B D$ & 1,3 & $2.81 \mathrm{NS}$ & $0.62 \mathrm{NS}$ & 3,3 & $4.12 \mathrm{NS}$ & $0.10 \mathrm{NS}$ & 3,3 & $0.30 \mathrm{NS}$ & $0.21 \mathrm{NS}$ \\
\hline \multirow[t]{2}{*}{ Site } & $A G B D$ & 3,33 & $0.47 \mathrm{NS}$ & - & 3,33 & $2.96^{*}$ & - & 3,33 & $8.46^{* * *}$ & - \\
\hline & $B G B D$ & 3,3 & $1.26 \mathrm{NS}$ & - & 3,3 & $8.07 \mathrm{NS}$ & - & 3,3 & $0.38 \mathrm{NS}$ & - \\
\hline
\end{tabular}

$N$ number of trees per hectare, $G$ basal area per hectare, $A G B D$ aboveground basic density, $B G B D$ belowground basic density, $r$ Spearman correlation, $N S$ not significant at the $5 \%$ level

*Significant at the $5 \%$ level; **significant at the $1 \%$ level; ***significant at the $0.1 \%$ level 
Table 3 Intra-tree aboveground and belowground basic density variation for three mangrove species

\begin{tabular}{|c|c|c|c|c|c|c|c|}
\hline \multirow[t]{2}{*}{ Source of variation } & \multirow[t]{2}{*}{ Category } & \multicolumn{2}{|c|}{ A. marina } & \multicolumn{2}{|c|}{ S. alba } & \multicolumn{2}{|c|}{ R. mucronata } \\
\hline & & $d f$ & $F$ & $d f$ & $F$ & $d f$ & $F$ \\
\hline \multirow[t]{2}{*}{ Tree component } & $A G B D$ & 2,65 & $0.94 \mathrm{NS}$ & 2,58 & $6.83^{* * *}$ & 2,62 & $27.51 * * *$ \\
\hline & $B G B D$ & 1,9 & $99.65 * * *$ & 1,9 & $2.38 \mathrm{NS}$ & 1,9 & $74.25 * * *$ \\
\hline
\end{tabular}

Note: For aboveground basic density, the tree components include stem, branch and twig; for belowground basic density, they include root crown and root

$A G B D$ aboveground basic density, $B G B D$ belowground basic density, $N S$ not significant at the $5 \%$ level

*Significant at the $5 \%$ level; **significant at the $1 \%$ level; ***significant at the $0.1 \%$ level models resulted in a higher AIC. On the other hand, inclusion of species and tree-specific mean belowground basic density resulted in lower AIC. In this regard, the model with tree-specific mean belowground basic density (CM7) exhibited the best results.

Figure 3 summarises $95 \%$ confidence intervals of observed and predicted tree aboveground and belowground biomass. Predicted values are based on both common and species-specific models. Generally, the results showed that the species-specific models based on $d b h$ only (RE1, RE2, RE3, RE7, RE8 and RE9) and on both $d b h$ and $h t$ (RE4, RE5 and RE6) reported by Njana et al. (2016) were more accurate than the common models developed in this study (CM1, CM2, CM3, CM4, CM5, CM6, CM7 and CM8) and those reported by Njana et al. (2016) (FE1, FE2 and FE3).
For aboveground biomass, however, the differences in predictive power between the models were minimal (Fig. 3). For belowground biomass, the species-specific models reported by Njana et al. (2016) performed generally well. However, the performance of the common belowground biomass model (FE3) reported by Njana et al. (2016) varied with species and gave larger uncertainties than the common models developed in this study (CM5, CM6, CM7 and CM8).

\section{Discussion}

This study reports tree aboveground and belowground basic density values for three mangrove species in Tanzania. To our

Table 4 Accuracy and precision of tree aboveground biomass estimation using aboveground basic density as a conversion factor

\begin{tabular}{|c|c|c|c|c|c|}
\hline \multirow[t]{2}{*}{ Species } & \multirow[t]{2}{*}{ Basic density applied $^{\mathrm{a}}$} & \multirow[t]{2}{*}{$n^{\mathrm{b}}$} & \multicolumn{2}{|c|}{$95 \%$ confidence intervals $(\mathrm{kg})$} & \multirow{2}{*}{$\begin{array}{l}\text { MPE } \\
(\%)\end{array}$} \\
\hline & & & $\begin{array}{l}\text { Observed aboveground } \\
\text { biomass }\end{array}$ & $\begin{array}{l}\text { Estimated aboveground } \\
\text { biomass }\end{array}$ & \\
\hline \multirow[t]{4}{*}{ A. marina } & $\begin{array}{l}\text { Tree- and component-specific mean from this } \\
\text { study }\end{array}$ & 22 & $761.5 \pm 259.5$ & $763.2 \pm 273.2$ & $+0.2 \mathrm{NS}$ \\
\hline & Tree-specific mean from this study & 22 & $761.5 \pm 259.5$ & $759.5 \pm 272.9$ & $-0.3 \mathrm{NS}$ \\
\hline & Species-specific mean from this study (overall) & 22 & $761.5 \pm 259.5$ & $756.9 \pm 278.5$ & $-0.6 \mathrm{NS}$ \\
\hline & GWD database species-specific mean & 22 & $761.5 \pm 259.5$ & $806.0 \pm 298.8$ & $+5.8 \mathrm{NS}$ \\
\hline \multirow[t]{4}{*}{ S. alba } & $\begin{array}{l}\text { Tree- and component-specific mean from this } \\
\text { study }\end{array}$ & 12 & $536.3 \pm 181.6$ & $537.0 \pm 192.9$ & $+0.1 \mathrm{NS}$ \\
\hline & Tree-specific mean from this study & 12 & $536.3 \pm 181.6$ & $526.3 \pm 185.3$ & $-1.9 \mathrm{NS}$ \\
\hline & Species-specific mean from this study (overall) & 12 & $536.3 \pm 181.6$ & $491.6 \pm 158.8$ & $-8.3^{*}$ \\
\hline & GWD database species-specific mean & 12 & $536.3 \pm 181.6$ & $498.4 \pm 161.5$ & $-7.1 *$ \\
\hline \multirow[t]{4}{*}{ R. mucronata } & $\begin{array}{l}\text { Tree- and component-specific mean from this } \\
\text { study }\end{array}$ & 21 & $611.4 \pm 167.7$ & $600.7 \pm 166.4$ & $-1.7 \mathrm{NS}$ \\
\hline & Tree-specific mean from this study & 21 & $611.4 \pm 167.7$ & $577.4 \pm 157.7$ & $-5.6 * * *$ \\
\hline & Species-specific mean from this study (overall) & 21 & $611.4 \pm 167.7$ & $561.9 \pm 150.0$ & $-8.1 * * *$ \\
\hline & GWD database species-specific mean & 21 & $611.4 \pm 167.7$ & $649.2 \pm 174.3$ & $+6.2 * * *$ \\
\hline
\end{tabular}

NS not significant at the $5 \%$ level

${ }^{\text {a }}$ Basic densities from the Global Wood Density (GWD) database were $648 \mathrm{~kg} \mathrm{~m}^{-3}$ (A. marina), $509 \mathrm{~kg} \mathrm{~m}^{-3}$ (S. alba) and $814 \mathrm{~kg} \mathrm{~m}^{-3}$ (R. mucronata) n Number of sample trees ${ }^{\mathrm{b}}$ Includes only trees with $d b h \geq 15 \mathrm{~cm}$

*Significant at the $5 \%$ level; **significant at the $1 \%$ level; ***significant at the $0.1 \%$ level 


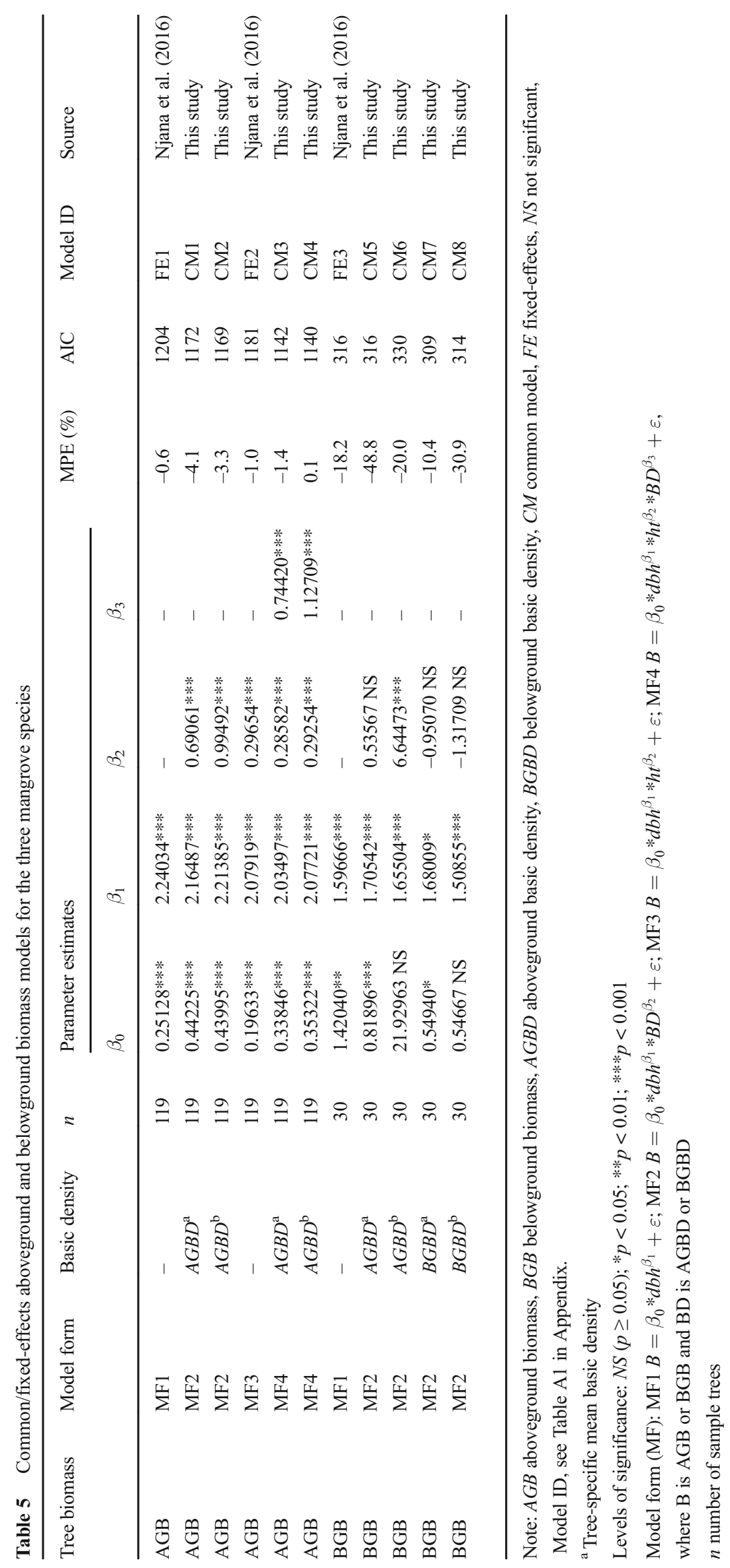


Fig. 3 Comparison of predictive accuracy of aboveground biomass $(A G B)(\mathbf{a})$ and belowground biomass $(B G B)$ (b) models (cf. list of models from Njana et al.

(2016) and Table 5 and Table A1 in Online Appendix). The bars represent mean values with their corresponding lower and upper $95 \%$ confidence limits. The grey dotted lines indicate $95 \%$ confidence limits for observed tree biomass values $(\mathrm{Obs})$
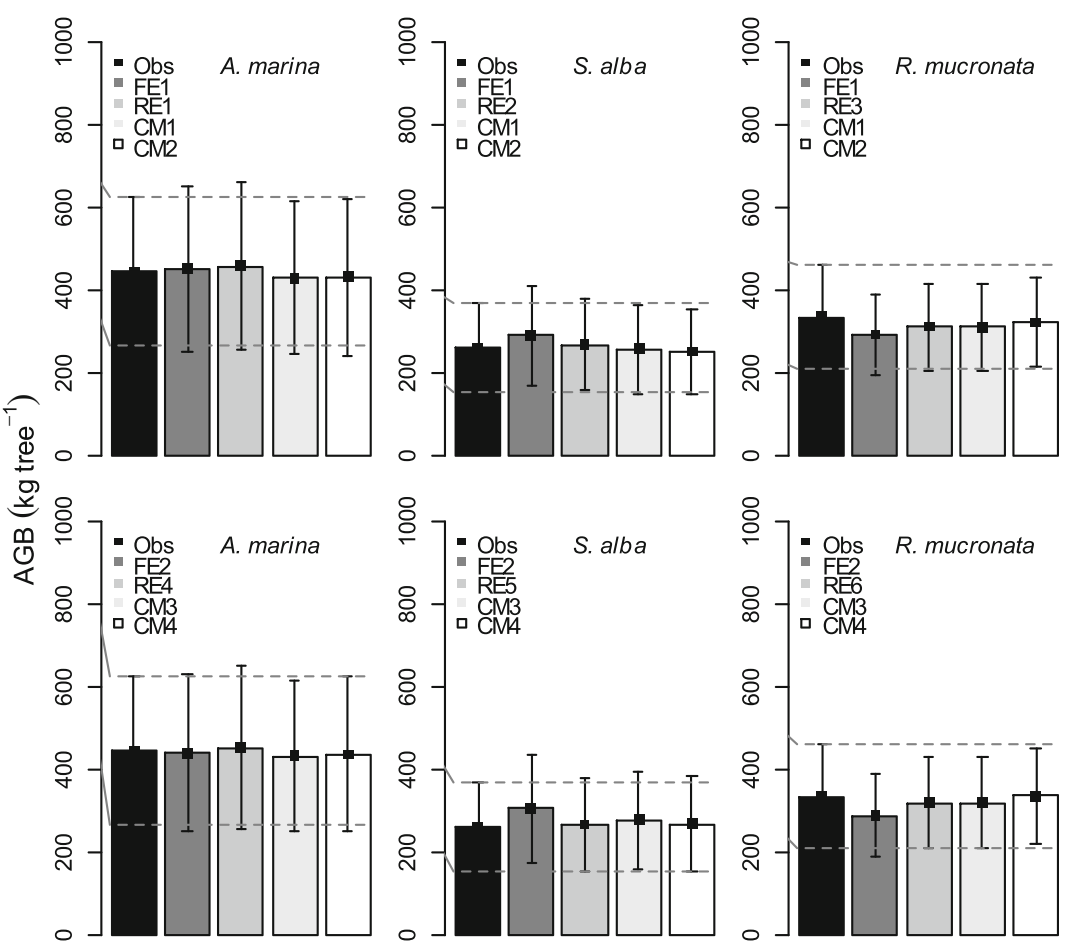

(a) AGB models
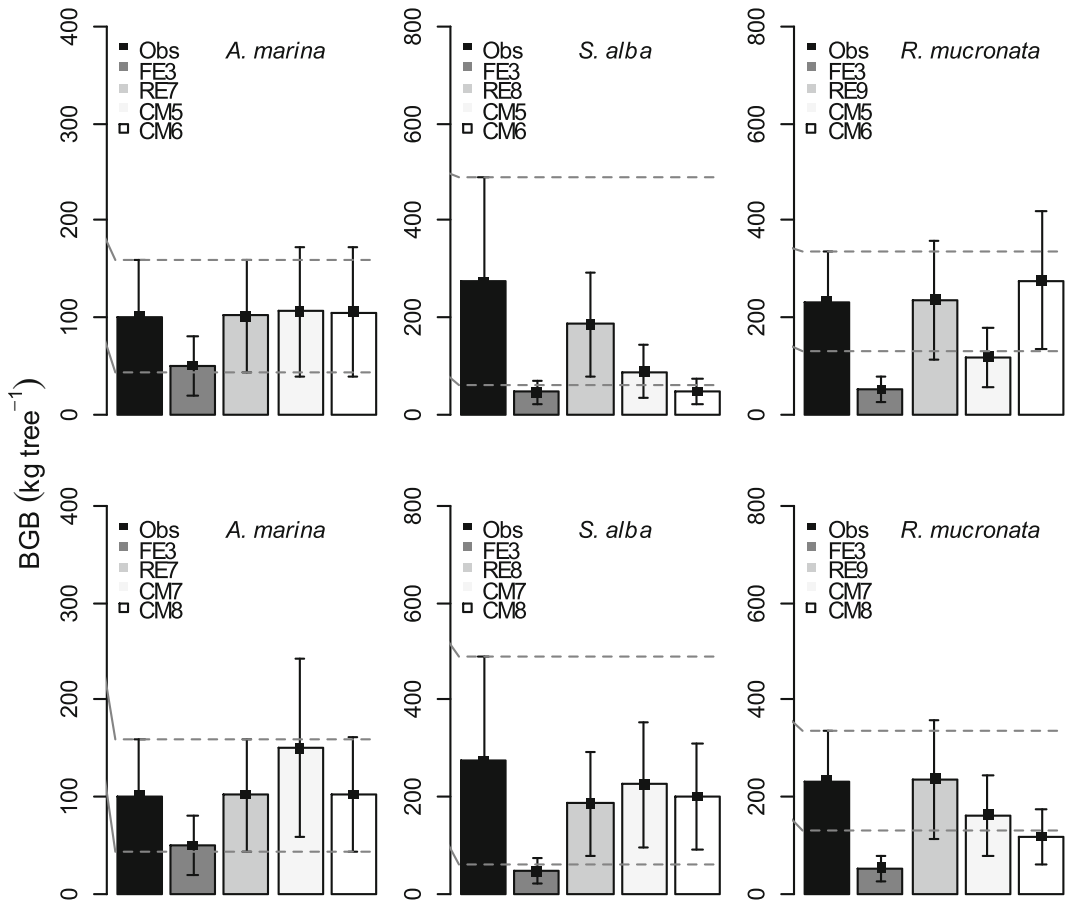

(b) BGB models knowledge, this is the first study to report belowground basic density for the three mangrove species. For a given species, it may be expected that different studies would yield similar values of tree basic density. Komiyama et al. (2005) reported a tree aboveground basic density value similar to our study for
R. mucronata. However, Komiyama et al. (2005) reported aboveground basic density values of $0.48 \pm 0.05 \mathrm{~g} \mathrm{~cm}^{-3}$ (STD) (S. alba) while Jachowski et al. (2013) reported aboveground basic density of $0.41 \pm 0.04 \mathrm{~g} \mathrm{~cm}^{-3}$ (STD) for $S$. alba. The aboveground basic density values reported in these 
studies are thus different from each other and very different from the aboveground basic density value of $0.54 \pm 0.04 \mathrm{~g} \mathrm{~cm}^{-3}$ (STD) estimated for S. alba in our study (Table 1).

The tree aboveground basic density values reported in our study also deviate from those reported in the GWD database (Chave et al. 2009; Zanne et al. 2009), where the values vary considerably. For example, tree aboveground basic density values for A. marina vary from 0.52 to $0.73 \mathrm{~g} \mathrm{~cm}^{-3}$ while for $S$. alba they vary from 0.39 to $0.63 \mathrm{~g} \mathrm{~cm}^{-3}$ (Chave et al. 2009; Zanne et al. 2009). The variation of these values exceeds the ranges (minimum-maximum) of the tree aboveground basic density values observed in our study for the same species. The variations of aboveground basic density noted between different studies may be due to, for example, differences in site conditions, basic density determination methods, sampling design and sample size. For instance, many aboveground basic density values reported in the GWD database were prepared to describe wood mechanical properties and may therefore be based on small samples from very few sites, thus reducing the generality of such basic density estimates. Generally, the variation in basic density between studies limits the reliability of results generated using aboveground basic density values as conversion factors for estimation of tree aboveground biomass.

We also found variation in basic density at species level, between trees (inter-tree) and within trees between tree components (intra-tree), and in some cases the variation was significant (Tables 2 and 3). Factors responsible for the between-tree variation included variation in $N, G$, tree size $(d b h)$ and site. All these factors were tested (Table 2), but their effects on basic density were mostly weak, particularly on belowground basic density. Genetic differences may also explain variation in aboveground and belowground basic density between trees. Within trees, for example, basic density variation along stem may be due to variation in the proportion of wood versus bark, heartwood versus sapwood, proportion of juvenile wood and growth rate. In our study, however, aboveground and belowground basic density values did not vary significantly between sites for A. marina. Contrary to our findings, Saintini et al. (2012) found different aboveground basic density values at different sites for A. marina. Saintini et al. (2012) reported that the growth rate of $A$. marina was positively correlated with xylem vessel size and aboveground basic density and concluded that high wood density was associated with large xylem vessels and thick fibre walls. Similarly, in our study we found that aboveground basic density values were significantly correlated with $d b h$ (S. alba and R. mucronata, Table 3) implying that aboveground basic density increases with tree size up to a particular threshold.

The variation of aboveground and belowground basic density between and within tree components observed in our study generally showed the importance of implementing an appropriate sampling strategy for determination of basic density values for biomass estimation and related applications. The nature of variation in basic density with stem sampling height for example suggests that sampling for aboveground basic density should ensure that basic density variation along the stem is sufficiently accounted for. Sampling of basic density at a fixed tree height by e.g. coring or disc extraction at $1.3 \mathrm{~m}$ (Williamson and Wiemann 2010) for trees of different sizes is likely to provide a good description of aboveground and belowground basic density variation with $d b h$ but ignores basic density variation between and within tree components.

We also tested the accuracy of indirect method for estimation of tree aboveground biomass where volume is first determined and then converted from volume to dry weight using aboveground basic density as conversion factor (Table 4). Both the direct and indirect method may be employed when sampling and measuring trees to generate data for the purpose of modelling (Brown 1997; Picard et al. 2012). The use of indirect method is particularly recommended for large trees as a means of reducing costs (Brown 1997). The results from our study showed that direct and indirect methods for estimation of tree aboveground biomass gave consistent and unbiased estimates of tree aboveground biomass when applying tree- and component-specific aboveground basic density values (Table 4).

The relatively large and significant MPE values that were found when applying species-specific aboveground basic density from the GWD database ( $S$. alba and R. mucronata, Table 4) indicate that basic density sourced from the GWD database may lead to biased local biomass estimates. This calls for inclusion of all sources of variation in determination of aboveground basic density as a volume to dry weight conversion factor and shows that basic density values from the GWD database need to be used with caution. Uncertainty due to the use of basic density as a conversion factor may be propagated into subsequent stages of biomass estimation, for example when tree aboveground biomass estimates are used in model development (e.g. Henry et al. 2010; Mwakalukwa et al. 2014). Both uncertainty due to aboveground basic density and the model itself affect estimates at the tree, stand and landscape levels. This is also the case when landscape tree volume estimates are converted into tree aboveground biomass using aboveground basic density (IPCC 2006; Somogyi et al. 2007).

Based on the conservative principle that the risk of overand under-estimation should be minimised (Grassi et al. 2008), during destructive sampling for estimation of tree aboveground biomass, we recommend the direct method (weighing) for estimation of tree aboveground biomass. The indirect method should only be applied when it is not practically feasible to use the direct method (e.g. very large trees). 
The following considerations are also essential in order to minimise uncertainties; when using the indirect method, tree- and component-specific aboveground basic density values should be applied. Moreover, when using the indirect method, we recommend working with a large number of observations (sample size $\geq 30$ ) which helps ensuring normally distributed residuals and unbiased estimates.

This study also examined the importance of using aboveground and belowground basic density in modelling aboveground and belowground biomass, respectively. Generally, species-specific mean aboveground and belowground basic densities were significant in explaining variations of tree aboveground and belowground biomass, respectively (Table 5). This points to the importance of applying aboveground basic density as a predictor variable for aboveground biomass and belowground basic density as a predictor variable for tree belowground biomass, contrary to the existing practice of applying aboveground basic density in modelling tree belowground biomass (e.g. Komiyama et al. 2005).

The results obtained in this study demonstrated that even with the use of mixed-effects modelling approach, inclusion of aboveground and belowground basic density as predictor variables for tree aboveground and belowground biomass respectively further improved goodness of fit of fixed-effects models (Table 5). This result is contrary to what was suggested by Njana et al. (2016) where the authors argued that it was not necessary to include aboveground and/ belowground basic density in order to improve the predictive accuracy of the models since the non-linear mixed-effects modelling approach is robust in distinguishing species using species as a random-effects variable.

The fact that basic density values in our data varied significantly between species and that the predictive accuracy of the common models including species-specific mean aboveground basic density were better than the common models based on $d b h$ only, or $d b h$ and $h t$ (Table 5) demonstrates the importance of including basic density when modelling tree biomass for multiple species data. Similarly, previous studies have successfully developed common biomass models for mixed species mangrove forests by incorporating aboveground basic density (e.g. Komiyama et al. 2005; Chave et al. 2005). Whether these studies developed their common aboveground biomass models using tree-specific aboveground basic density or species-specific mean aboveground basic density or both is not clear. If both tree-specific and species-specific mean basic density values are mixed up in modelling tree biomass, they are likely to lead to confounding effects (i.e. model quality will be affected by a mix of both tree-specific and species-specific mean basic density variations). Mixing up tree-specific and species-specific mean basic density values should therefore be avoided. Instead, for cases where basic density varies between species and with tree size, and where tree basic density data or basic density models are available, tree biomass may be modelled using tree-specific basic density. Otherwise, in the absence of tree-specific basic density, tree biomass may be modelled using species-specific mean basic density. The use of tree-specific basic density implies that basic density accounts for both species and tree $d b h$ variations, while the use of species-specific mean basic density accounts for variation between species only.

The common aboveground and belowground biomass models including basic density performed better than the common models based on $d b h$ and $h t$ reported by Njana et al. (2016). However, the species-specific models based on $d b h$ and $h t$ (Njana et al. 2016) turned out to be superior to the common models including basic density developed in the present study. Moreover, given the fact that aboveground basic density values from the GWD database were observed to be inaccurate and that aboveground and belowground basic density generally varies between species (Table 1) and sites (Table 2), application of common models including such predictor variables would require determination of site-specific basic density so as to ensure that such models perform as observed in this study. Using common models including basic density is therefore inefficient, both economically and statistically, and we therefore recommend using the species-specific models reported by Njana et al. (2016) for estimation of tree aboveground and belowground biomass for relevant mangrove species in Tanzania.

\section{Conclusions}

Basic density is important for various applications including conversion of tree volume to biomass (conversion factor) and prediction of tree biomass. The study found that tree aboveground and belowground basic density varied between species and within species. Accordingly, sampling for estimation of basic density should take into account all sources of variation. Accurate estimation of tree biomass is essential for REDD+ and 808 forest management in general. The use of tree- and component-specific basic density values as a volume-biomass conversion factor resulted in relatively accurate tree aboveground estimates. However, the use of species-specific mean and basic density values sourced from the GWD database may lead to biased tree aboveground biomass estimates; therefore, such undertakings should be done cautiously. On the other hand, common aboveground and belowground biomass models including basic density performed better than the common models developed without aboveground/belowground basic density previously. This demonstrates the importance of aboveground and belowground basic density in modelling tree aboveground and belowground biomass, respectively. However, the species-specific models developed without basic density were better than the common models including basic density. Therefore, we recommend the use of species-specific biomass 
models developed without basic density rather than common models including density.

Acknowledgments The authors would like to thank Tanzania Forest Service field officers D. Mnyagi (Pangani), S. K. Nyabange (Bagamoyo), H. Mallya (Rufiji) and M. C. Mbago (Mtwara) for facilitation and logistical support during field work. In addition, we would like to thank our field assistants and boat driver for their perseverance and hard work. Thanks are also due to the anonymous reviewer and the handling editor whose comments helped to improve the manuscript. We are also indebted to the Climate Change Impacts and Adaptation Mitigation (CCIAM) Programme for granting a $\mathrm{PhD}$ scholarship to the first author and financing field work.

Contribution of co-authors M. A. Njana: took part in design of research, responsible for data collection and preparation, data analysis and manuscript development

H. Meilby: framing the study and provide technical guidance on data analysis and commenting on the manuscript

T. Eid: took part in design of the research, supervising the work, commenting on the manuscript

E. Zahabu: supervising the work and commenting on the manuscript

R. Malimbwi: coordinating the design of research project and commenting on the manuscript

\section{Compliance with ethical standards}

Conflict of interest The authors declare that they have no conflict of interest.

Funding The work reported here was financed by the CCIAM Programme and the research project Enhancing the Measuring, Reporting and Verification (MRV) of forests in Tanzania through the cooperation between the Government of the United Republic of Tanzania and the Kingdom of Norway.

\section{References}

Aksornkoae S, Maxwell GS, Havanond S, Panichsuko S (1992) Plants in mangroves. IUCN Asian Regional Office, Bangkok

Alongi DM (2011) Carbon payments for mangrove conservation: ecosystem constraints and uncertainties of sequestration potential. Environ Sci Pol 14:462-470

Angelsen A, Hofstad O (2008) Inputs to the development of a National Reducing carbon Emissions from Deforestation and forest Degradation (REDD) strategy in Tanzania, Norwegian University of Life Sciences (UMB). Report for the Norwegian Embassy in Tanzania

Auty D, Achim A, Macdonald E, Cameroon AD, Gardiner BA (2014) Models for predicting wood density variation in Scots pine. Forestry $87: 449-458$

Bretz F, Hothorn T, Westfall P (2011) Multiple comparisons using R. CRC Press, New York

Brown S (1997) Estimating biomass change of tropical forests: Primer, FAO Forestry Paper 134, Rome, Italy

Chave J, Condit R, Aguilar S, Hernandez A, Lao S, Perez R (2004) Error propagation and scaling for tropical forest biomass estimates. Philos Trans R Soc London B 359:409-420

Chave J, Andalo C, Brown S, Cairns MA, Chambers JQ, Eamus D, Fölster H, Fromard F, Higuchi N, Kira T, Lescure JP, Nelson B, Ogawa H, Puig H, Riéra B, Yamakura T (2005) Tree allometry and improved estimation of carbon stocks and balance in tropical forests. Oecologia 145:87-99

Chave J, Coomes DA, Jansen S, Lewis SL, Swenson NG, Zanne AE (2009) Towards a worldwide wood economics spectrum. Ecological Lett 12(4):351-366

Clark DC, Kellner JR (2012) Tropical forest biomass estimation and the fallacy of misplaced concreteness. J Veg Sci 23:1191-1196

Comley BWT, McGuinness KA (2005) Above- and belowground biomass, and allometry of four common northern Australian mangroves. Aust J Bot 53:431-436

Donato DC, Kauffman JB, Murdiyarso D, Kurnianto S, Stidham M, Kanninen M (2011) Mangroves among the most carbon-rich forests in the tropics. Nat Geosci 4:293-297

Duncan C, Primavera JH, Pettorelli N, Thompson JR, Loma RJA, Koldewey HJ (2016) Rehabilitating mangrove ecosystem services: A case study on the relative benefits of abandoned pond reversion from Panay Island, Philippines. Marine Pollution Bulletin 109: 772782

FAO (2010) Global Forest Resource Assessment 2010. FAO Forestry Paper 163. Rome, Italy

Fatoyinbo TE, Simard M, Washington-Allen RA, Shugart H (2008) Landscape-scale extent, height, biomass, and carbon estimation of Mozambique's mangrove forests with Landsat ETM+ and shuttle radar topography mission elevation data. Geophys Res 113:1-14

Fearnside PM (1997) Wood density for estimating forest biomass in Brazilian Amazonia. Forest Ecol Manag 90:59-87

Gałecki A, Burzykowski T (2013) Linear mixed-effects models using R: a step by step approach. Springer, New York

Githiomi JK, Kariuki JG (2010) Wood basic density of Eucalyptus grandis from plantations in central rift valley, Kenya: variation with age, height level and between sapwood and heartwood. J Trop For Sci 22:281-286

Grassi G, Monni S, Federici S, Achard F, Mollicone D (2008) Applying the conservativeness principle to REDD to deal with the uncertainties of the estimates. Environ Res Lett 3:1-11

Henry M, Besnard A, Asante WA, Eshun J, Adu-Bredu S, Valentini R (2010) Wood density, phytomass variations within and among trees and allometric equations in a tropical rainforest of Africa. Forest Ecol Manag 260:1375-1388

IPCC (2003) IPCC good practice guidance for LULUCF. Institute for Global Environmental Strategies (IGES) for the IPCC. Kanagawa, Japan

IPCC (2006) Guidelines for National Greenhouse Gas Inventories. IGES, Japan

Jachowski NRA, Quak MSY, Friess DA, Duangnamon D, Webb EL, Ziegler AD (2013) Mangrove biomass estimation in South-west Thailand using machine learning. Appl Geogr 45:311-321

Ketterings QM, Coe R, van Noordwijk M, Ambagau Y, Palm CA (2001) Reducing uncertainty in the use allometric biomass equations for predicting aboveground tree biomass in mixed secondary forests. Forest Ecol Manag 146:199-209

Komiyama A, Poungparn S, Kato S (2005) Common allometric equations for estimating the tree weight of mangroves. J Trop Ecol 21: 471-477

Komiyama A, Ong JE, Poungparn S (2008) Allometry, biomass, and productivity of mangrove forests: a review. Aquat Bot 89:128-137

Kristensen E, Bouillon S, Dittmar T, Marchand C (2008) Organic carbon dynamics in mangrove ecosystems: a review. Aquat Bot 89:201219

Langner A, Miettinen J, Siegert F (2007) Land cover change 2002-2005 in Borneo and the role of fire derived from MODIS imagery. Glob Change Biol 13:2329-2340

Locatelli T, Binet T, Kairo JG, King L, Madden S, Patenaude G, Upton C, Huxham M (2014) Turning the tide: how blue carbon and payments for ecosystem services (PES) might help save mangrove forests. Ambio 43:981-995 
Luoga EJ, Malimbwi RE, Kajembe GC, Zahabu E, Shemwetta DTK, Lyimo-Macha J, Mtakwa P, Mwaipopo CS (2004) Tree species composition and structures of Jasini Mkwajuni mangrove forest at Pangani, Tanzania. J Tanzan Assoc For 10:42-47

MNRT (Ministry of Natural Resources and Tourism) (2015) NAFORMA (National Forest Monitoring and Assessments of Tanzania) main results. Dar es Salaam

Mwakalukwa EE, Meilby H, Treue T (2014) Volume and aboveground biomass models for dry miombo woodlands in Tanzania. Intern J For Res doi. doi:10.1155/2014/531256

Nagelkerken I, Blaber SJM, Bouillon S, Green P, Haywood M, Kirton LG, Meynecke JO, Pawlik J, Penrose HM, Sasekumar A (2008) The habitat function of mangroves for terrestrial and marine fauna: a review. Aquat Bot 89:155-185

Njana MA, Eid T, Zahabu E, Malimbwi R (2015) Procedures for quantification of belowground biomass of three mangrove tree species. Wetlands Ecol and Manage 23:749-764

Njana MA, Bollandsås OM, Eid T, Zahabu E, Malimbwi RE (2016) Above- and belowground tree biomass models for three mangrove species in Tanzania: a non-linear mixed-effects modelling approach. Ann For Sci 73:353-369

Nshare JS, Chitiki A, Malimbwi RE, Kinana BM, Zahabu E (2007) The current status of the mangrove forest along seashore at Salenda bridge, Dar es Salaam, Tanzania. J Tanzan Assoc For 11:172-179

Ong JE, Gong WK, Wong CH (2004) Allometry and partitioning of the mangrove, Rhizophora apiculata. Forest Ecol Manag 88:395-408

Picard N, Saint-André L, Henry M (2012) Manual for building tree volume and biomass allometric equations: from field measurement to prediction. Food and Agricultural Organization of the United Nations, Rome, and Centre de Coopération Internationale en Recherche Agronomique pour le Développement, Montpellier

Pinheiro J, Bates D (2000) Mixed effects models in S and S-plus. Springer, New York

Purnobasuki H (2013) Characteristics of root caps in four root types of Avicennia marina (Forsk.) Vierh. Am J P Sci 4:853-858

R Core Team (2013) R: a language and environment for statistical computing. R Foundation for Statistical Computing, Vienna. http://www.R-project.org/. Accessed 20 Nov 2013

Saenger P, Hegerl EJ, Davie JDS (eds) (1983) Global status of mangrove ecosystems by the Working Group on Mangrove Ecosystems of the IUCN Commission on Ecology in cooperation with the United Nations Environment Programme and the World Wildlife Fund. Environmentalist 3:1-88

Saintini NS, Schmitz N, Lovelock CE (2012) Variation in wood density and anatomy in a widespread mangrove species. Trees 26:1-9
Somogyi Z, Cienciala E, Mäkipää R, Muukkonen P, Lehtonen A, Weiss P (2007) Indirect methods of large-scale forest biomass estimation. Eur J Forest Res 126:197-207

Spalding M, Kainuma M, Collings L (2010) World atlas of mangroves. A collaborative project of ITTO, ISME, FAO, UNEPWCMC, UNESCO-MAB, UNU-INWEH and TNC. Earthscan, London

Tamooh F, Huxham M, Karachi M, Mencuccini M, Kairo JG, Kirui B (2008) Below-ground root yield and distribution in natural and replanted mangrove forests at Gazi bay, Kenya. Forest Ecol Manag 256:1290-1297

Tomlinson PB (1986) The botany of mangroves. Cambridge University Press, Cambridge

UNFCCC (2011) United Nations Framework Convention on Climate Change (2011) Outcome of the Ad Hoc Working Group on Longterm Cooperative Action Under the Convention (Draft Decision [-/CP.17])

Valiela I, Bowen JL, York JK (2001) Mangrove forests: one of the world's threatened major tropical environments. Bioscience 51:807-815

Walther BA, Moore JL (2005) The concepts of bias, precision and accuracy, and their use in testing the performance of species richness estimators, with a literature review of estimator performance. Ecography 28:815-829

West PW (2009) Tree and forest measurements. 2nd edition. SpringerVerlag, Berlin Heidelberg

Wiemann MC, Williamson GB (2012) Density and specific gravity metrics in biomass research. USDA Forest Service, Forest Products Laboratory, General Technical Report, FPL-GTR-208

Williamson GB, Wiemann MC (2010) Measuring wood specific gravity correctly. Am J Bot 97:519-524

Wylie L, Sutton-Grier AE, Moore A (2016) Keys to successful blue carbon projects: lessons learned from global case studies. Mar Policy 65:76-84

Zanne AE, Lopez-Gonzalez G, Coomes DA, Ilic J, Jansen S, Lewis SL, Miller RB, Swenson NG, Wiemann MC, Chave J (2009) Data from: towards a worldwide wood economics spectrum. Dryad Digital Repository. doi:10.5061/dryad.234

Zhang K, Liu H, Xu H, Shen J, Rhome J, Smith TJ (2012a) The role of mangroves in attenuating storm surges. Estuar Coast Shelf S 103:11-23

Zhang L, Deng X, Lei X, Xiang W, Peng C, Lei P, Yan W (2012b) Determining stem biomass of Pinus massoniana $\mathrm{L}$. through variations in basic density. Forestry 85:601-609

Zhou X, Brandle JR, Schoeneberger MM, Awada T (2007) Developing above-ground woody biomass equations for open-grown, multiplestemmed tree species: shelterbelt-grown Russian-olive. Ecol Model $20: 311-323$ 